
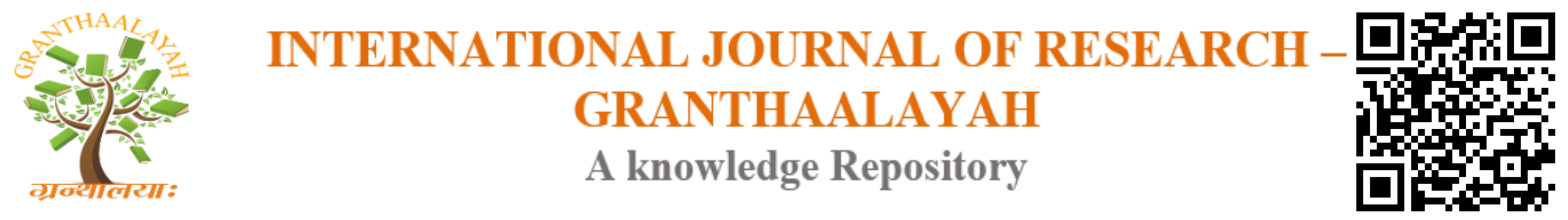

Management

\title{
OCCUPATIONAL HAZARDS IDENTIFICATION AND THEIR RISK ASSESSMENT DURING THE CONSTRUCTION OF HEAD RACE TUNNEL IN MIDDLE BHOTEKOSHI HYDROELECTRIC PROJECT
}

\author{
Chheku Lama ${ }^{1}$, Dinesh Prasad Sah ${ }^{2}$, Anjay Kumar Mishra ${ }^{3}$ \\ ${ }^{1}$ Civil Engineer (Head RaceTunnel \& Surge Tank Incharge), Madhya Bhotekoshi Jalvidut \\ Company Limited, Maharajgung Kathmandu, Nepal \\ 2 OSH Expert, SMS Environment \& Engineering Pvt.Ltd., Nepal \\ ${ }^{3}$ Visiting Faculty and Management Consultant, United Technical College, Nepal
}

\begin{abstract}
Construction of hydro power tunnel generates lots of occupational hazards. Due to different types of occupational hazards prevailed in tunnel construction, occupational accidents and diseases may affect health and safety of the workers. The main objective of this research was to identify the occupational hazards and assess their risks level. Head Race Tunnel of Middle Bhotekoshi Hydroelectric Project-102MW (MBKHEP) was selected for the study. This study has been carried out by utilizing the data collected from the duly filled semi structured questionnaires by the Employers', Consultants' and Contractors' personnel. Moreover and key informant interview.

Risk level of rock fall hazard has been revealed as the highest with risk score of 21.5 and fall under "Critical" risk level rating. Electric hazard and vibration have been found to have the risk score of 16 and 13.35 respectively both having "High" level of risk rating. Toxic gases like ammonia gases etc., dust hazards, hot and humid work environment, heat and humidity, tripping, ergonomics, chemical spills, oxygen deficiency, lighting, noise/sound and unprotected edges have been found to have risk scores $10,10,9.5,9.215,9,8.65,8.1,8.1,7.6,6.75,6$ respectively which all fall under the risk level rating of "Moderate". Other hazards having "Low" risk rating level were alcoholism, fall from platform, job dissatisfaction, job Insecurity, hit by aggregate, radiations, mechanical struck, slippery, snake bites, water inundation, deadline pressure and bat biting with respective risk scores $5.25,4.8,4.6,4.45,4.3,4,4,4,4,3,2.85,2$.
\end{abstract}

Keywords: Degree of Accident; Critical Risk; High; Moderate Risk.

Cite This Article: Chheku Lama, Dinesh Prasad Sah, and Anjay Kumar Mishra. (2019). "OCCUPATIONAL HAZARDS IDENTIFICATION AND THEIR RISK ASSESSMENT DURING THE CONSTRUCTION OF HEAD RACE TUNNEL IN MIDDLE BHOTEKOSHI HYDROELECTRIC PROJECT." International Journal of Research - Granthaalayah, 7(3), 227-248. https://doi.org/10.29121/granthaalayah.v7.i3.2019.965. 


\section{Introduction}

Occupational safety and health (OSH) is the well-being of workers at their workplaces regarding their health \& safety. A good condition of OSH boosts the employee productivity. OSH is generally defined as the science that anticipate, recognize, evaluate and control the hazards arising in or from the workplace that could impair the health and well-being of workers, taking into account the possible impact on the surrounding communities and the general environment(Alli, 2008).

Hydropower projects are one of the most important infrastructure development projects in the developed as well as developing part of the world. Construction of hydropower project is the most versatile in nature as it consists of construction of many civil structures like access roads, dam construction, diversion tunnel, desander, gravel traps, flushing canal, fore bay, canal, adit tunnel, access tunnel, test tunnel, head race tunnel, surge tank, surge shaft tunnel, power house, tailrace etc. and associated mechanical and electrical works like mechanical gates such as under sluice, radial gates, switchyard, pressure conduit, penstock pipe, generator, control panel, transformer, Corporate Social Responsibility(CSR) projects, transmission line projects, crusher plants, batching plants etc.

The peer view in Nepalese construction industry reveals that the majority of the construction works, in present days, are those of hydropower construction. Some of them are either in construction phase or in various stages of planning. Many hydro projects are about to complete and many hydropower projects are under feasibility study, many projects have done financial closure. Many multi-purpose hydro power projects are under study. Even though, some of the small hydropower projects uses the canal, box culvert and steel pipe as the conveyance system for convey the water, almost all the medium and large scale hydro power projects use the head race tunnel (HRT) due to mountainous and irregular rocky terrain as the conveyance system to convey the water from intake to surge tank through pressurized flow of water. Sometimes almost all the structures of hydropower are constructed underground. Rasuwagadhi HEP (111MW) is good example for underground hydro power project whose all structures are designed as underground (DPR of Rasuwagadhi HEP). Construction projects may use different processing methods like Auto processing, Semi Auto processing \& Manual Processing methods. Construction of Head Race Tunnel of Middle Bhotekoshi Hydroelectric Project (MBKHEP) having the installed capacity of 102MW is using Semi Auto processing method. Semi Auto processing method uses workers as well as equipment, machines etc. for construction works. Workers involved in construction activities of tunnel may expose too many kinds of potential occupational hazards.

This study will help to bring forth the occupational hazards during construction of HRT. It will also help to assess the risk level of those hazards. This study will document the preventive and control measures implemented during construction of HRT. This study will help to reveal the effectiveness of preventive and control measures implemented during the construction of HRT.

The main objective of this research is to identify the prevailing occupational hazards and assessment of their risk during the construction of head race tunnel (HRT) of Middle Bhotekoshi Hydroelectric Project (MBKHEP). 


\section{Literature Review}

\subsection{Occupational Hazards}

The meaning of the word hazard may be confusing. Often specific definitions are not found in dictionaries or found it with the term "risk". For example, one dictionary defines hazard as "a danger or risk" which helps explain why many people use the terms interchangeably.

There are many definitions for hazard but the most common definition when talking about workplace health and safety is:

A hazard is any source of potential damage, harm or adverse health effects on something or someone.

The CSA Z1002 Standard "Occupational health and safety - Hazard identification and elimination and risk assessment and control" uses the following terms:

- Harm - physical injury or damage to health.

- Hazard - a potential source of harm to a worker.

Basically, a hazard is the potential to cause harm or an adverse effect (for example, to people as health effects, to organizations as property or equipment losses, or to the environment).

Sometimes the resulting harm is referred to as the hazard instead of the actual source of the hazard. For example, the disease tuberculosis (TB) might be called a "hazard" by some but, in general, the TB-causing bacteria (Mycobacterium tuberculosis) would be considered the "hazard" or "hazardous biological agent"(Ccohs, 2012).

As per (ILO, 1996), there are an unlimited number of hazards that can be found in almost any workplace. There are obvious unsafe working conditions, such as unguarded machinery, slippery floors or inadequate fire precautions, but are also a number of categories of insidious hazards (that is, those hazards that are dangerous but which may not be obvious) including:

- chemical hazards, arising from liquids, solids, dusts, fumes, vapoursand gases;

- physical hazards, such as noise, vibration, unsatisfactory lighting, radiation and extreme temperatures;

- biological hazards, such as bacteria, viruses, infectious waste and infestations;

- psychological hazards resulting from stress and strain;

- hazards associated with the non-application of ergonomic principles,for example badly designed machinery, mechanical devices and tools used by workers, improper seating and workstation design, or poorly designed work practices.

\subsection{Occupational Accident}

According to Heaven (2012), an occupational accident can be defined as an undesired or unfortunate or unplanned event that happens with no intention in the occupational works places and generally causes harm, injury, damage of property and also fatal injury during the construction activities at site. Accident also causes loss of life, economic losses, morale down of workers 
ultimately decreasing productivity of workers. Accidents consist of many direct as well as indirect costs losses. Construction activities involve lots of hazardous materials, plant and equipment, tools, manpower etc. due to which accident takes place at work places. Generally, major accident happens due to hardware based and software based causes. Hardware based causes involve tools \& equipment, materials, process, physiological condition of workers, psychology of workers, drinking alcohol and taking drugs, unsuitable as well as improper personal protective equipment. Software based causes include inadequate plan and program, improper safety plan, lack of training, lack of signage and signals, improper training materials, errors, mistakes and negligence. In general, accident can be categorized as follows according to Heaven (2012).

- Falling from height.

- Falling from scaffolding.

- Falling from ladder.

- Falling from the work place.

- Falling of an object.

- Accident with Machine.

- Accident with broken glasses

- Use of dangerous Chemicals.

- Under water work and dewatering.

- Blasting work.

- Slip, trip and low fall

- Crush injury

- Fire hazard

- Deep Excavation

$>$ Collapse of side wall.

$>$ Falling from edge of excavation.

$>$ Falling of object from edge of excavation

\subsection{Occupational Diseases in Construction Project}

Some occupational diseases have been recognized for many years, and affect workers in different ways depending on the nature of the hazard, the route of exposure, the dose, etc. Some well-known occupational diseases include:

- asbestosis (caused by asbestos, which is common in insulation, automobilebrake linings, etc.);

- $\quad$ silicosis (caused by silica, which is common in mining, sandblasting,etc.);

- lead poisoning (caused by lead, which is common in battery plants,paint factories, etc.);

and noise-induced hearing loss (caused by noise, which is common in many workplaces, including airports, and workplaces where noisy machines, such as presses or drills, etc. are used). There are also a number of potentially crippling health problems that can be associated with poor working conditions, including:

- heart disease;

- musculoskeletal disorders such as permanent back injuries or muscledisorders;

- allergies;

- reproductive problems; 
- stress-related disorders.

Many developing countries report only a small number of workers affected by work-related diseases. These numbers look small for a variety of reasons that include:

- inadequate or non-existent reporting mechanisms;

- a lack of occupational health facilities;

- a lack of health care practitioners who are trained to recognize work-related diseases.

Because of these reasons and others, it is fair to assume that in reality, the numbers of workers afflicted with occupational diseases are much higher. In fact, overall, the number of cases and types of occupational diseases are increasing, not decreasing, in both developing and industrialized countries (ILO, 1996).

\subsection{Risk Assessment}

Risk Assessment is defined as the process of assessing the risks associated with each of the hazards identified so the nature of the risk can be understood. This includes the nature of the harm that may result from the hazard, the severity of that harm and the likelihood of this occurring (Western Sydney University, 2015).

As part of managing the health and safety of our business, we must control the risks in our workplace. To do this we have to think about what might cause harm to people and decide whether we are taking reasonable steps to prevent that harm. This is known as risk assessment and it is something we are required by law to carry out. If we have fewer than five employees we don't have to write anything down. A risk assessment is not about creating huge amounts of paperwork, but rather about identifying sensible measures to control the risks in our workplace. We are probably already taking steps to protect our employees, but our risk assessment will help us decide whether we have covered all we need to. For some risks, other regulations require particular control measures. Our assessment can help us identify where we have to look at certain risks and these particular control measures in more detail. These control measures do not have to be assessed separately but can be considered as part of, or an extension of, our overall risk assessment (HSE, 2014).

\subsubsection{Risk Assessment Procedure}

As per Western Sydney University (2015), the risk assessment procedure can best be illustrated in the following way. 


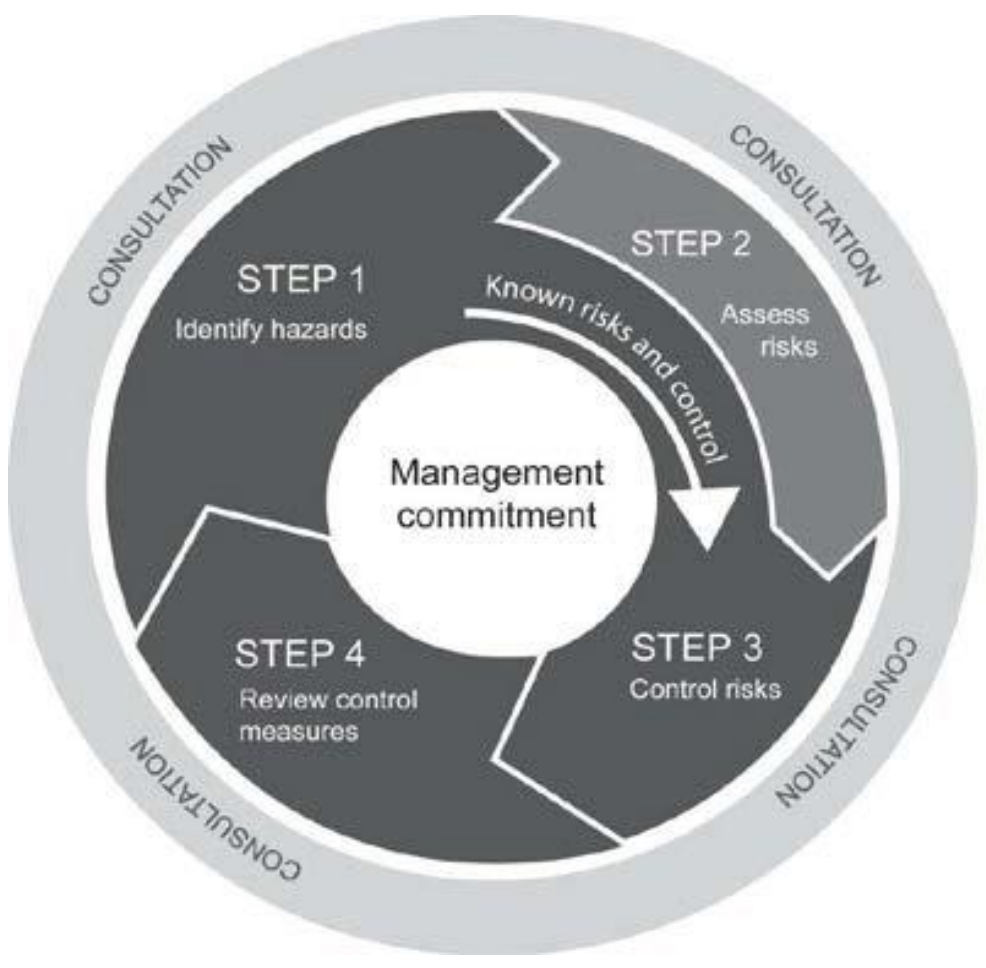

Figure 2.1: Risk assessment: source (WSU, 2015)

\section{Step 1: Identify Hazards}

WHS legislation in New South Wales requires that PCBUs, in consultation with workers identify all potentially hazardous things or situations that may cause harm. In general, hazards are likely to be found in the following;

- Physical work environment,

- Equipment, materials or substances used,

- Work tasks and how they are performed,

- Work design and management

In order to identify hazards the following are recommended:

1) Past incidents/accidents are examined to see what happened and whether the incident/accident could occur again.

2) Employees be consulted to find out what they consider are safety issues, I.e. ask workers about hazards near misses they have encountered as part of their work. Sometimes a survey or questionnaire can assist workers to provide information about workplace hazards.

3) Work areas or work sites be inspected or examined to find out what is happening now. Identified hazards should be documented to allow further action. The work environment, tool and equipment as well as tasks and procedures should be examined for risks to WHS.

4) Information about equipment (e.g. plant, operating instructions) and Material Safety Data Sheets be reviewed to determine relevant safety precautions.

5) Welcome creative thinking about what could go wrong takes place, i.e. what hazardous event could take place here? 


\section{Step 2: Assess Risks}

Risk assessment involves considering the possible results of someone being exposed to a hazard and the likelihood of this occurring. A risk assessment assists in determining:

- How severe a risk is.

- Whether existing control measures are effective.

- What action should be taken to control a risk?

- How urgently action needs to be taken.

A risk assessment should include:

1) Identify factors that may be contributing to the risk,

2) Review health and safety information that is reasonably available from an authoritative source and is relevant to the particular hazard,

3) Evaluation of how severe the harm could be. This includes looking at the types of injuries/illnesses/harm/damage that can result from the hazard, the number of people exposed, possible chain effects from exposure to this hazard.

4) Evaluation of how a hazard may cause harm. This includes examining how work is completed, whether existing control measures are in place and whether they control the harm, looking at infrequent/abnormal situations as well as standard operating situations. A chain of events related to a risk may need to be considered.

5) Determining the likelihood of harm occurring. The level of risk will increase as the likelihood of harm and its severity increases. The likelihood of harm occurring may be affected by how often the task is completed, in what conditions, how many people are exposed to the hazard and for what duration.

6) Identify the actions necessary to eliminate or control the risk; and

7) Identify records that it is necessary to keep to ensure that the risks are eliminated or controlled. Other risk factors should also be identified as they may contribute to the risk: including

8) The work premises and the working environment, including their layout and condition,

9) The capability, skill, experience and age of people ordinarily undertaking work,

10) The systems of work being used; and

11) The range of reasonably foreseeable conditions.

The process of assessing the risk is undertaken by reviewing any available information about the hazard (e.g. legislation, Australian Standards, Industry Code of Practice or guidance material about the hazard) and by using your personal work experience about what sort harm the hazard could create and how likely this would be to happen. When determining how likely it is that a person could be exposed to a hazard, consideration needs to be given to these "exposure factors":

1) Whether there are any other risk factors that increase the likelihood of exposure?

2) How often is the person exposed (frequency)?

3) or how long is the person exposed (duration)?

4) How many people are exposed?

5) the likely dose to which the person is exposed?

6) any legislative or recommended exposure levels required by statutory authorities. 
Risk Rating Matrix

\begin{tabular}{|c|c|c|c|c|}
\hline \multicolumn{5}{|c|}{ Likelihood(L) } \\
\hline Consequences & Rare & Unlikely Possible & Very Likel & Certain to occur \\
\hline Catastrophic & moderate & moderatehigh & critical & critical \\
\hline Major & low & moderatemoderate & high & critical \\
\hline Moderate & low & moderatemoderate & moderate & high \\
\hline Minor & Very low & moderate & moderate & moderate \\
\hline Insignificant & Very low & Very lowlow & low & moderate \\
\hline
\end{tabular}

\begin{tabular}{|l|l|}
\hline $\begin{array}{l}\text { Consequences } \\
\text { (C) }\end{array}$ & How Severely Could Someone be Hurt? \\
\hline Catastrophic & Death of permanent disability \\
\hline Major & Serious injury, hospital treatment required \\
\hline Moderate & Injury requiring medical treatment and some lost time \\
\hline Minor & Minor injury, first aid only required \\
\hline Insignificant & Injury requiring no treatment or first aid \\
\hline Likelihood & How Likely are the consequences? \\
\hline L) & \\
\hline Certain to occur Expected to occur in most circumstances \\
\hline Very Likely & Will probably occur in most circumstances \\
\hline Possible & Might occur occasionally \\
\hline Unlikely & Could happen sometime \\
\hline Rare & May happen only in exceptional circumstances \\
\hline
\end{tabular}

\begin{tabular}{|l|l|}
\hline $\begin{array}{l}\text { Risk Level } \\
\text { Rating }\end{array}$ & Required Action \\
\hline Critical & $\begin{array}{l}\text { Immediate action needed. Access to the hazard should be restricted until the risk can } \\
\text { be lowered to an acceptable level. Short term action may be required to lower the risk } \\
\text { level and then medium and long term plans to control the risk to as low as reasonably } \\
\text { practicable using the Hierarchy of Controls. }\end{array}$ \\
\hline High & $\begin{array}{l}\text { Action needed quickly (within 1-2 days). The task should not proceed unless the risk } \\
\text { is assessed and control options selected based on the Hierarchy of Controls. }\end{array}$ \\
\hline Moderate & $\begin{array}{l}\text { Action required this week to eliminate or minimize the risk using the Hierarchy of } \\
\text { Controls. }\end{array}$ \\
\hline Low & $\begin{array}{l}\text { Action required within a reasonable timeframe (2-4 weeks) eliminating or minimizing } \\
\text { the risk using the Hierarchy of Controls. }\end{array}$ \\
\hline Very Low & Risk to be eliminated or lowered when possible using the Hierarchy of Controls. \\
\hline
\end{tabular}

\section{Actions Required}

\section{Step 3: Controlling Risks}

Once a risk rating is determined, each hazard must have its existing risk control measures evaluated using the Evaluation of Control Effectiveness Table. This allows for determination of any additional requirement necessary. 


\section{Study Population and Sample Selection}

Even though the sample size was proposed as $100 \%$, during the questionnaire survey 3 workers could not be assessed. 37 workers out of 40 have been assessed for survey along with 100\% client/ consultant and contractor.

Table 3.1: Total population size

\begin{tabular}{|l|l|l|}
\hline Total Population Size (No of Personnel from) \\
\hline Client/Consultant Employers(contractor) & Workers \\
\hline 12 & 10 & $40($ only 37 were assessed.) \\
\hline
\end{tabular}

\subsection{Method of Data Collection}

Both primary and secondary data were required for the accomplishment of this research.

\subsubsection{Primary Data}

\section{Site Observation}

Site observation has been used as one of the data collection mode to identify different occupational hazards.

\section{Key Informant Interview}

For the pretest of the questionnaire, key informant interview (KII) were taken with the experts of related sector, local peoples etc. The KII was based on the snowball sampling. This interview was taken by meeting the expert of related field. Five experts were chosen for the KII and all of them had experience of more than ten years in the hydropower \& tunneling sector.

\section{Questionnaire Survey}

After the pretest of questionnaire, the questionnaires were distributed to the respondent of client /consultant and contractor's Manager/Officers/Engineers (employers) and workers for questionnaire Survey. All the questionnaires were distributed by visiting them.

\subsubsection{Secondary Data}

Secondary data as literature review was done.

\subsection{Data Analysis}

Microsoft Excel was used.

\section{Risk Score}

Risk score has been calculated by multiplying consequences (C) and likelihood (L) as shown in risk rating matrix. The rating of consequences (1-5) for different hazards have been provided based on the responses of respondents responses from questionnaire survey for and past records of health problems due to particular hazard as well as based on judgment and prediction that how severely 
someone could be hurt due to that particular hazard. Similarly, the rating of likelihood (1-5) for different hazards have been provided based on the responses from questionnaire survey for and past records of frequency of occurrence, based on judgement and prediction that how likely the consequences are as well as KII with experts for particular hazard.

\section{Risk level rating}

After calculating the risk scores of different occupational hazards prevailing, they have been placed in reverse chronological order to provide the risk level rating. As per foundation-stone-ofOHSAS-18001, risk level of 20-25 is used for extreme risk/critical risk, risk level of 12-18 for high risk, 6-10 for moderate risk and risk score 1-5 is used for low risk.

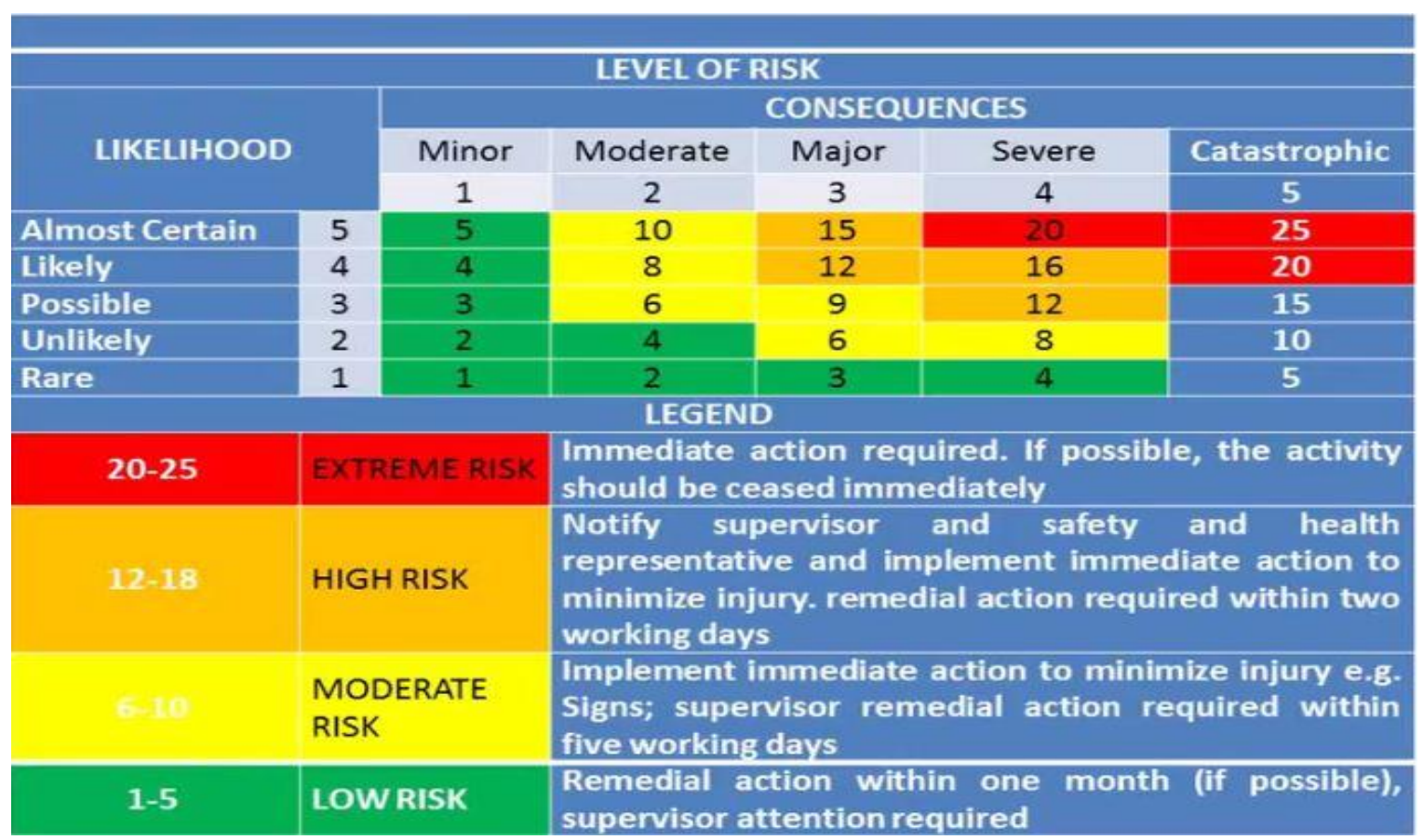

Figure 3.1: Risk assessment matrix (OHSA 18001)

\section{Research Matrix:}

Research Objectives

To identify the occupationalTypes of hazards, exposure of hazards and assess their risklevel hazards, Health Impact, Risk Score etc. Data collection method

- Site observation

- KII

- Questionnaires

- Past records

\section{Occupational Hazards}

\subsection{Common Physical Hazards Prevailing in Tunnel}

Table 4.1 summarizes that exactly $100 \%$ employers and $86 \%$ workers responded that Noise was the leading physical hazard in tunnel construction. About $71 \%$ employers responded that vibration was the second most common physical hazards while $97 \%$ workers responded that Heat and Humidity was the second most common physical hazards in the tunnel construction. But $43 \%$ 
employers responded that heat and humidity was the third most leading physical hazard while 49\% workers responded that radiation was the third most leading physical hazards in the tunnel construction. It was observed that only noise, vibrations, heat and humidity were major physical hazards prevailing in tunnel. Radiations were not observed at tunnel site.

Table 4.1: The most common physical hazards

\begin{tabular}{|c|c|c|c|c|}
\hline & \multicolumn{2}{|c|}{ Employers } & \multicolumn{2}{|c|}{ Workers } \\
\hline & Number & Percentage & Number & Percentage \\
\hline Most common Physical Hazards Noise & 7 & $100 \%$ & 32 & $86 \%$ \\
\hline Electric Shock & 2 & $29 \%$ & 10 & $27 \%$ \\
\hline Lighting & 1 & $14 \%$ & 9 & $24 \%$ \\
\hline Vibrations & 5 & $71 \%$ & 30 & $81 \%$ \\
\hline Heat \& Humidit & 3 & $43 \%$ & 36 & $97 \%$ \\
\hline Radiations & 1 & $14 \%$ & 18 & $49 \%$ \\
\hline
\end{tabular}

\subsubsection{Common Mechanical Hazards}

Table 4.2 shows that $71 \%$ employers responded that slippery, rock sliding, rock mass fall were the equally leading mechanical hazards while in workers view, $86 \%$ agreed that Rock mass fall was the leading mechanical hazards in tunnel. 57\% of employers responded that fall from platform and hit by aggregate was second equally leading mechanical hazards while $65 \%$ workers responded that rock sliding was the second most leading mechanical hazards in tunnel. $46 \%$ workers responded that tunnel was slippery inside. $43 \%$ workers responded hit by aggregate during shot creting was another mechanical hazard in tunnel construction. It was observed that rock mass fall, rock sliding and slippery were the common mechanical hazards at site.

Table 4.2: The most common sources of mechanical hazards

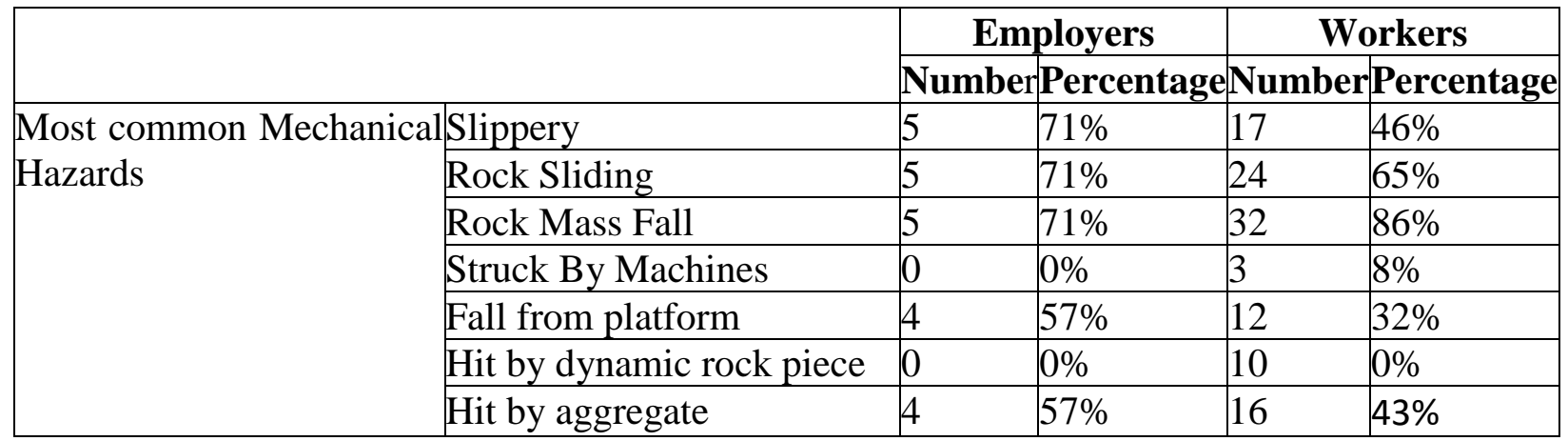

\subsubsection{Common Chemical Hazards}

According to table 4.3 , exactly $100 \%$ employers and $81 \%$ workers responded that Chemical spills were the most common chemical hazards followed by $71 \%$ employers silica/sand dust was another chemical hazard in tunnel. About $86 \%$ of employers responded that cement dust was second leading chemical hazards while $73 \%$ workers responded that cement dust, silica dust and sand dust were second most equally leading chemical hazards in tunnel. About $65 \%$ workers also responded for the toxic gases as prevailed chemical hazard in tunnel. It was also observed that chemical dusts 
like cement, sand, silica dusts, chemical spills and toxic gases were the most common chemical hazards at site.

Table 4.3: The most common chemical hazards

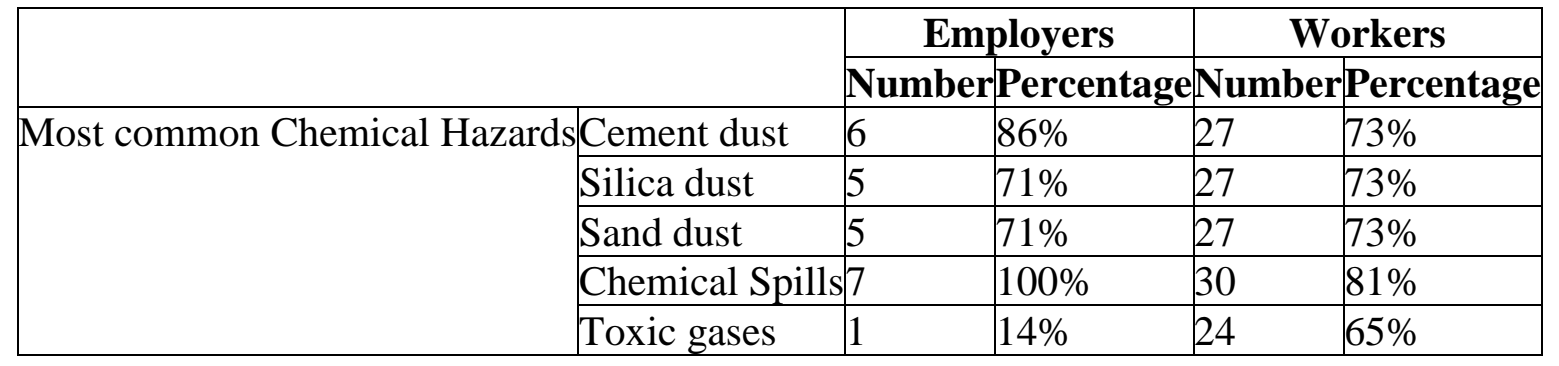

\subsubsection{Access to Drinking Water}

Figure 4.1 shows that $51 \%$ workers responded that they had access to drinking water as well as toilet while $49 \%$ workers responded that they had no access to drinking water and toilet i.e. there were almost equal chances of biological hazards for the workers enrolled in tunnel construction. In the observation, it was seen that drinking water for workers was directly from source and was not made any treatment and filter and toilet was not neat and clean. So there was a high chance of water borne diseases.

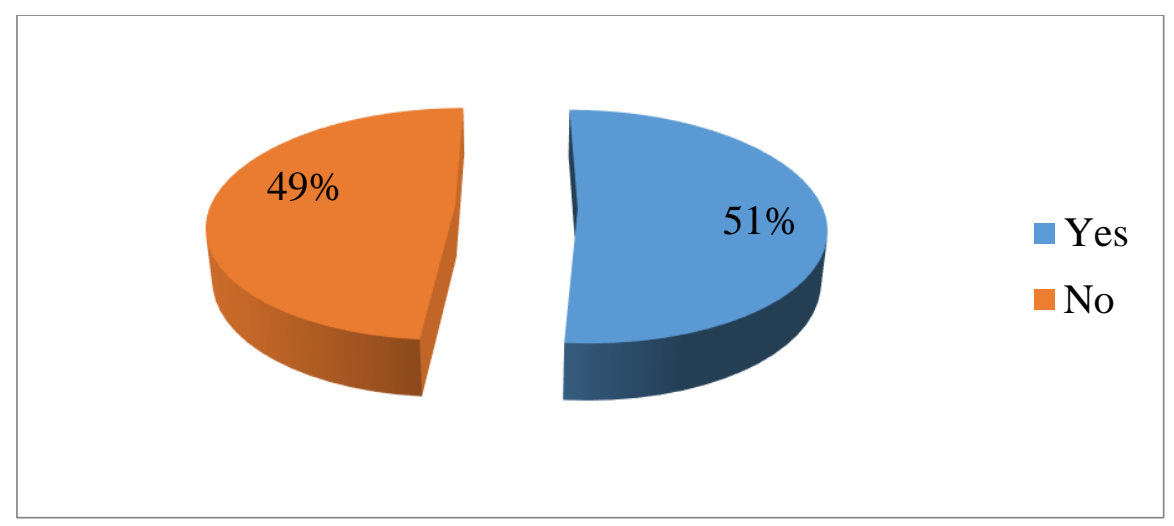

Figure 4.1: Access to drinking water and toilet

Toilet and bathroom was not neat and clean which seems to be prone of bacterial as well as viral contamination and can lead to communicable diseases. There is a high chance of biological hazards

Drinking water was brought directly from natural spring source but was not made any treatment in the reserve tank. Distance between drinking water storage and toilet was not kept far enough. So, there is a chance of contamination of the drinking water.

\subsubsection{Major Causes of Psychosocial Hazards}

Figure 4.2 summarizes that $92 \%$ of workers have job dissatisfaction which is followed by $89 \%$ job insecurity, 35\% alcoholism and wage and leave as prevailed psychosocial hazards during the construction of HRT. 


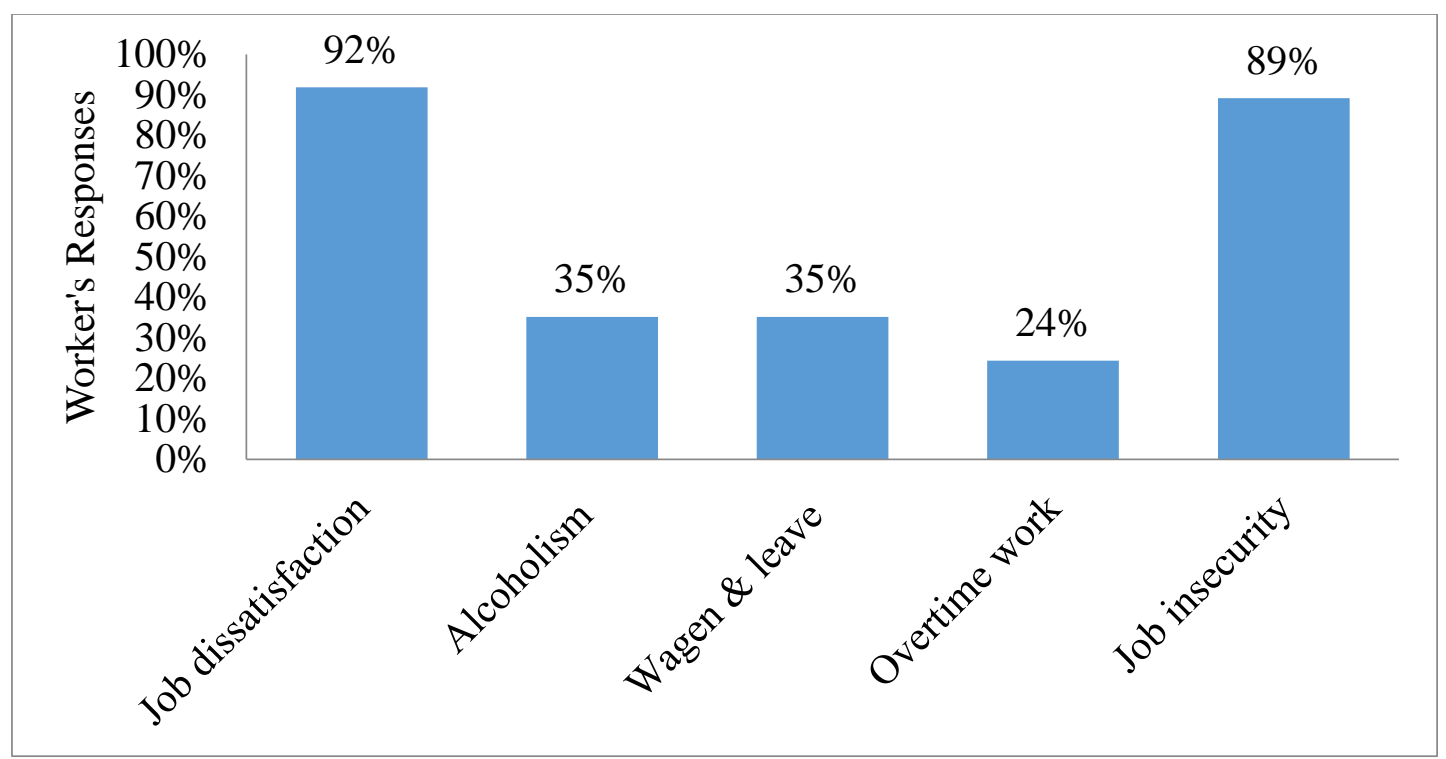

Figure 4.2: Major causes of psychosocial hazards

\subsubsection{Work Related Stress}

Figure 4.3 shows the results of work related stress at site. About $95 \%$ workers responded that they were suffered from hot $\&$ humid work environment followed by $81 \%$ oxygen deficiency and finally $57 \%$ deadline pressure.

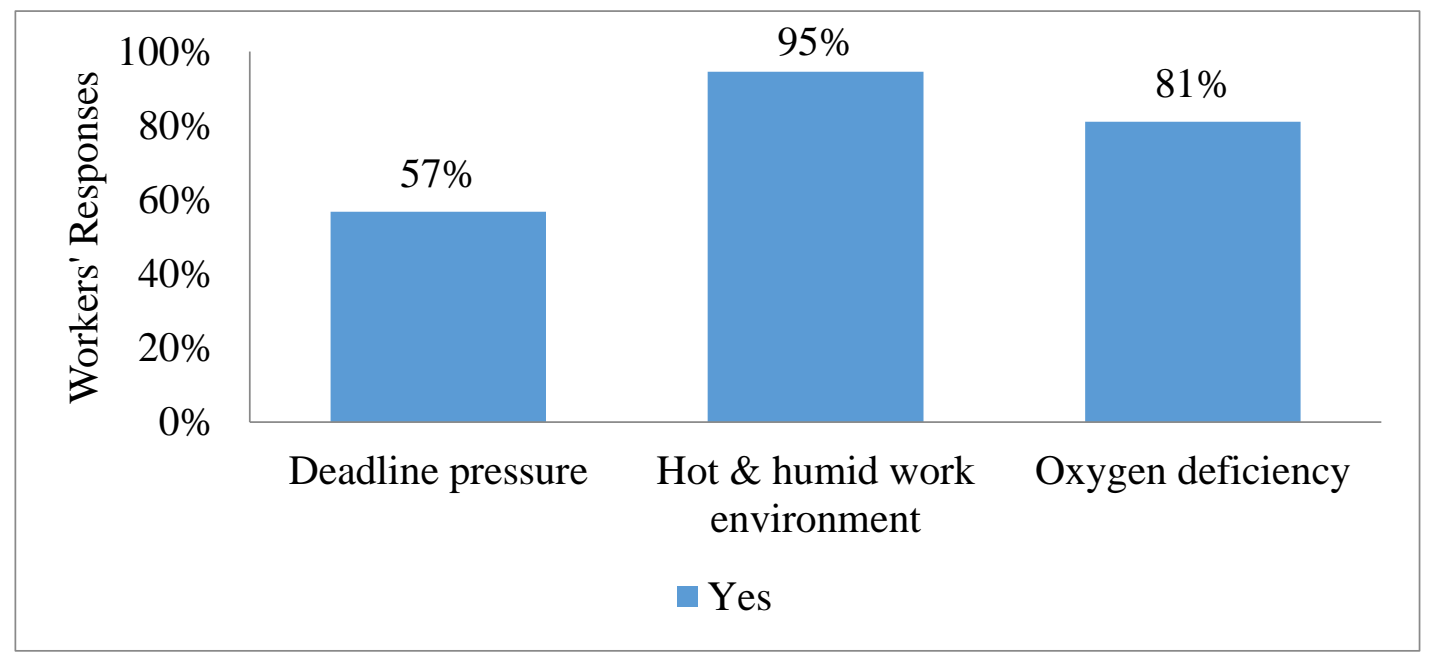

Figure 4.3: Work Related Stress

It was observed that hot environment inside tunnel occurred near face after the blasting of face since face gets pressurized and heated for some hours. If there is seepage water from the crown and other part of tunnel then hot \& humid work environment is combinely experienced inside tunnel. During mucking by excavator, loader, dump truck etc. hot environment is felt as these equipment gets heated during operation. During drilling \& loading the face, hot\& humid environment is felt as jack hammer used gets extremely heated. Due to heat sweating on body of driller occurs. Immediately after the blasting, since there are toxic gases released from face, defuming must be done through air duct by starting the blower fans. Immediately after face 
blasting, due to toxic gases released, no operation of oxygen/air duct and some oxygen already present there are polluted; there occurs the situation of extreme oxygen deficiency inside tunnel. At least 30 minutes or more time is required for defuming out the toxic gases \& smoke coming out from blast. During mucking equipment used release toxic gases and smokes, oxygen deficiency takes place. During shotcreting, as lots of cement/silica/sand dusts are released oxygen deficiency is occurred.

There will mostly be the deadline pressure to the personnel of Lot1 Civil contractor involved in the construction since they are always pressurized by the delay claim made from personnel of Lot 2 Contractor as Hydro Mechanical part always follow the Civil construction part. Sometimes if progress of tunnel lags as compared to the headworks and powerhouse and other part then deadline pressure increase to the personnel involved in the construction of HRT.

\subsection{Risk Assessment}

\subsubsection{Major Health Problems}

Table 4.4 shows the results of Major health Problems. About 57\% employers responded that workers complained them about Back pain and Wrist pain each as major complains followed by $29 \%$ of employers who responded that they received deaf as another complain from workers. While about $89 \%$ of workers responded that they suffered from Wrist pain followed by $84 \%$ Back pain.

Table 4.4: Major health problems

\begin{tabular}{|l|l|l|l|l|}
\hline \multirow{2}{*}{ Major Health Problems } & \multicolumn{2}{|c|}{ Employers } & \multicolumn{2}{r|}{ Workers } \\
\cline { 2 - 5 } & Numbers & Percentage & Numbers & Percentage \\
\hline Hearing loss & 2 & $29 \%$ & 14 & $38 \%$ \\
\hline Faint & 0 & $0 \%$ & 5 & $14 \%$ \\
\hline Back Pain & 4 & $57 \%$ & 31 & $84 \%$ \\
\hline Wrist Pain & 4 & $57 \%$ & 33 & $89 \%$ \\
\hline others & 0 & $0 \%$ & 2 & $5 \%$ \\
\hline
\end{tabular}

Whoever works in tunnel has the high chances of health problem like hearing loss, faint, back pain, wrist pain etc. In tunnel construction, Generator, Air compressor, blower fans etc. are placed near the portal face and jack hammer, shotcrete machines, excavator, loader, dump truck, shotcrete machine are used inside tunnel these equipment and machine and during blasting large noise/sound greater than human audible sound is released which causes hearing loss to the workers. During drilling, driller suffers from wrist pain and back pain. During operation of shotcrete machine operator also suffer from back pain and wrist pain.

\subsubsection{Health Problem Due to Physical Hazards}

Figure 4.4 summarizes the result of Health Problem due to Physical Hazards. About $76 \%$ of workers responded that they had health problem of eye strain. 


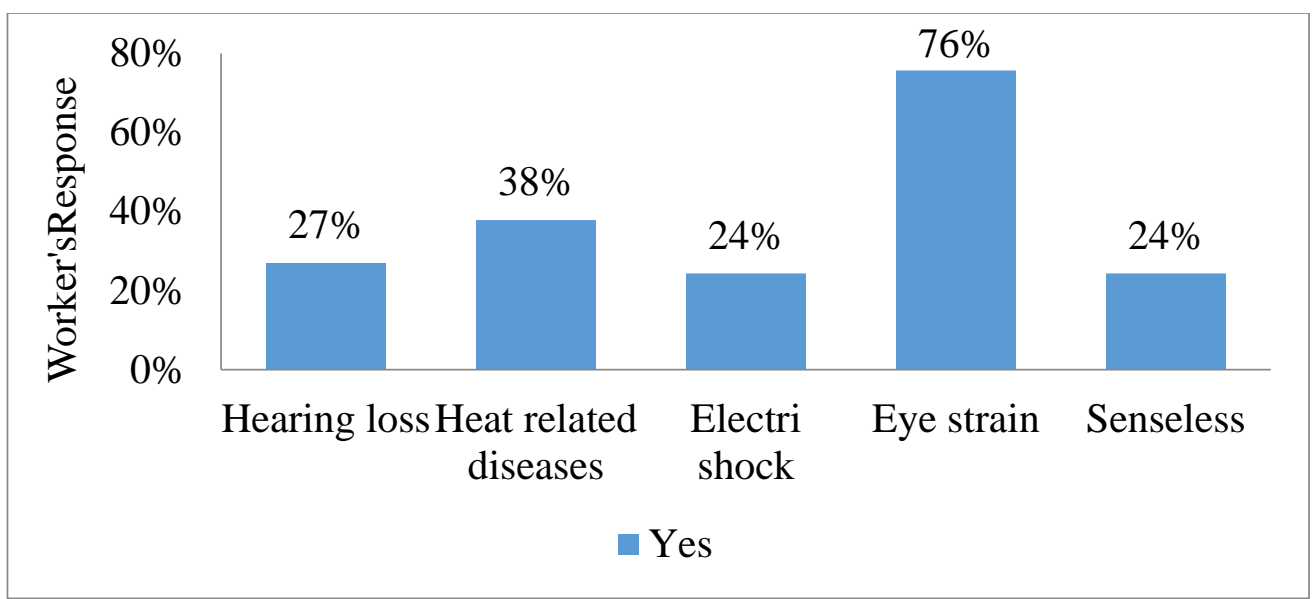

Figure 4.4: Health problems due to physical hazards

As all of workers responded that physical hazards was the top most type of prevailed hazards in tunnel construction, definitely there are more health problem due to physical hazards.

Different equipment used like excavator, loader etc., welding process and different lighting bulb release lighting of different intensity of light. Due to these lighting workers have the high chances of eye strain.

In tunnel construction, Generator, Air compressor, blower fans etc. are placed near the portal face and jack hammer, shotcrete machines, excavator, loader, dump truck, shotcrete machine are used inside tunnel these equipment and machine and during blasting large noise/sound greater than human audible sound is released which causes hearing loss to the workers. Since HRT of MBKHEP could not be the exception, there are high chances of hearing loss.

Since blasting of tunnel face, different equipment used such as generator, compressor, excavator, loader, dump truck, jack hammer, shotcrete machine etc. release very big amount of heat there is also a chances of heat related diseases.

\subsubsection{Health Problem Due to Chemical Hazards}

Table 4.5 shows that, $86 \%$ workers and $80 \%$ employer working in tunnel responded that allergy was the leading risk due to chemical hazard. Secondly, about $60 \%$ employers and $59 \%$ workers responded that irrigative was another risk due to Chemical Hazards followed by $30 \%$ employers and $27 \%$ workers who responded that Corrosive was third most risk due to Chemical Hazards.

Table 4.5: Health problem due to chemical hazards

\begin{tabular}{|l|l|l|l|l|}
\hline \multirow{2}{*}{ Suffers from } & \multicolumn{2}{l|}{ Employers } & \multicolumn{2}{l|}{ Workers } \\
\cline { 2 - 5 } & \multicolumn{2}{l}{ Numbers Percentage } & Numbers & Percentage \\
\hline Allergic & 8 & $80 \%$ & 32 & $86 \%$ \\
\hline Irritative & 6 & $60 \%$ & 22 & $59 \%$ \\
\hline Corrosive & 2 & $30 \%$ & 10 & $27 \%$ \\
\hline Chronic Bronchitis & 0 & $0 \%$ & 0 & $0 \%$ \\
\hline Carcinogenic & 0 & $0 \%$ & 0 & $0 \%$ \\
\hline
\end{tabular}


In tunnel different chemicals used are cement dust, silica dust; chemical admixtures like WRA, plasticizer, super plasticizers cause the allergy. As some workers responded that corrosive as the health problem due to these chemical hazards their dress, clothes, gloves were corroded. The workers skin of leg hand etc. was also corroded upto some extent. Although Chronic Bronchitis, Carcinogenic etc. are most common disease due to chemical hazards, no one responded for these diseases.

\subsubsection{Health Problem Due to Bad Ergonomics}

By key informant interviews of experts it was found that health problem of workers due to bad ergonomics was back pain and wrist pain. Simple platform was used during drilling and for other support works like shotcreting, rock bolting etc. due to which there is high chances of back pain, neck pain, leg pain etc.

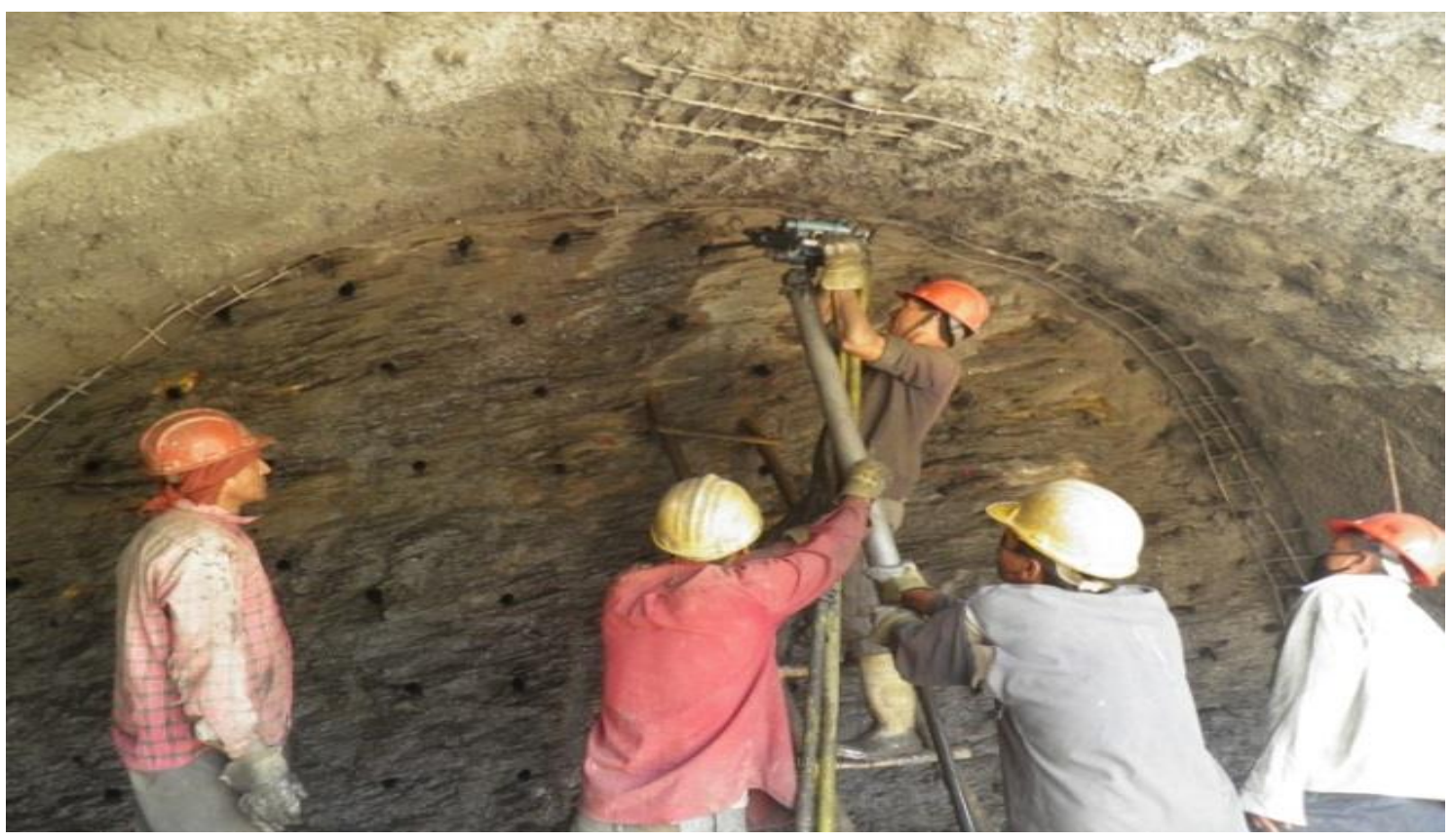

Pate 4.1: Bad ergonomics

Mainly bad ergonomics was during drilling in the face of tunnel as shown in Plate 4.1. Due to working like this workers suffer from the health problem like wrist pain, Arms pain and back pain etc.

\subsubsection{Risk of Rock Fall in Tunnel}

It was observed and from KII with experts that when there expose class of rock in increasing order then weaker the rock and higher the risks of falling the rock mass. When rock class is weaker then until and unless proper support workers should not be allowed to start the works. 


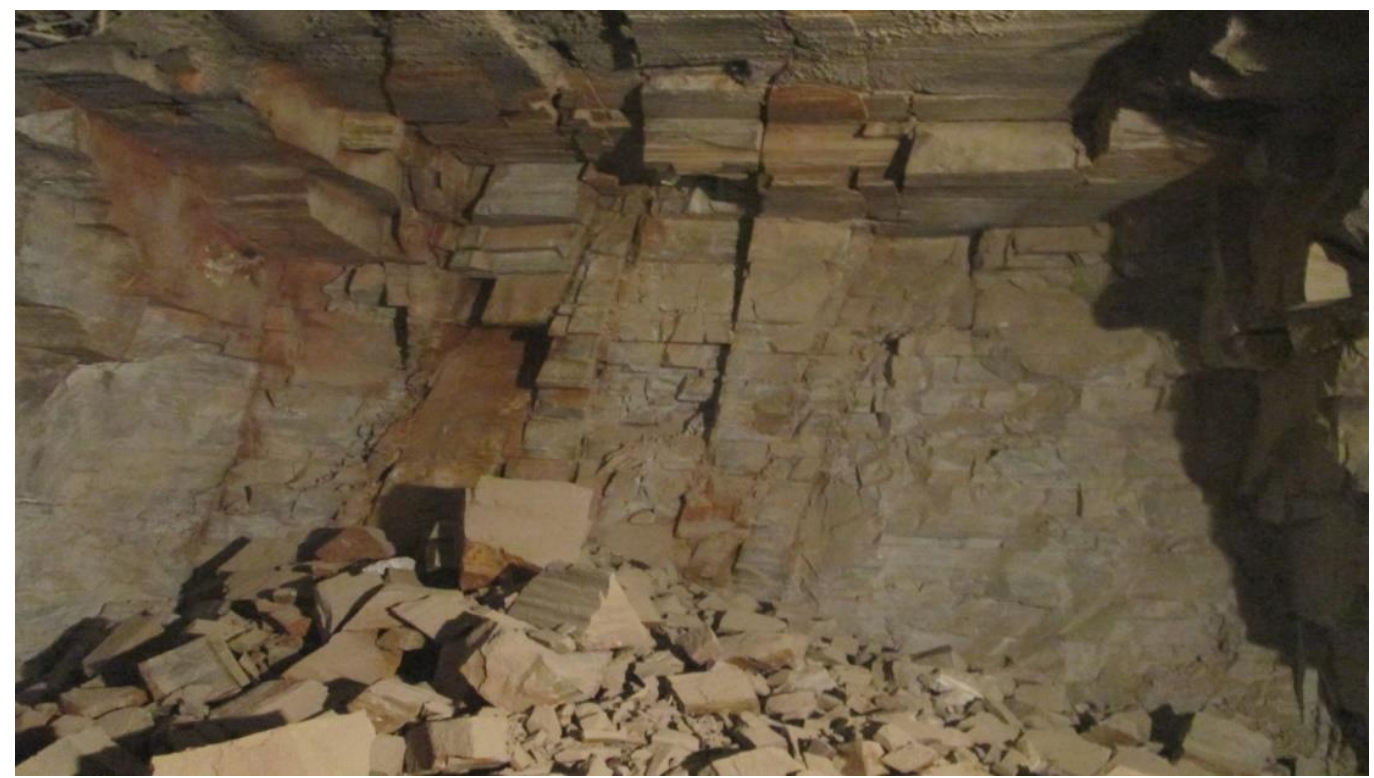

Plate 4.2: Showing risk of rock mass fall

Plate 4.2 shows the rock fall risk in tunnel. Weaker the rock, higher the risk of rock fall hazards inside tunnel. Proper scalling and mapping along with proper support works must be performed before doing the other works in tunnel.

\subsubsection{Risk of Seepage Water Inundation in Tunnel}

It was observed that inundation of seepage water in different section of tunnel. Water inundation can result in the accident of workers and other personnel involved in tunnel, machines and equipment, vehicles etc.

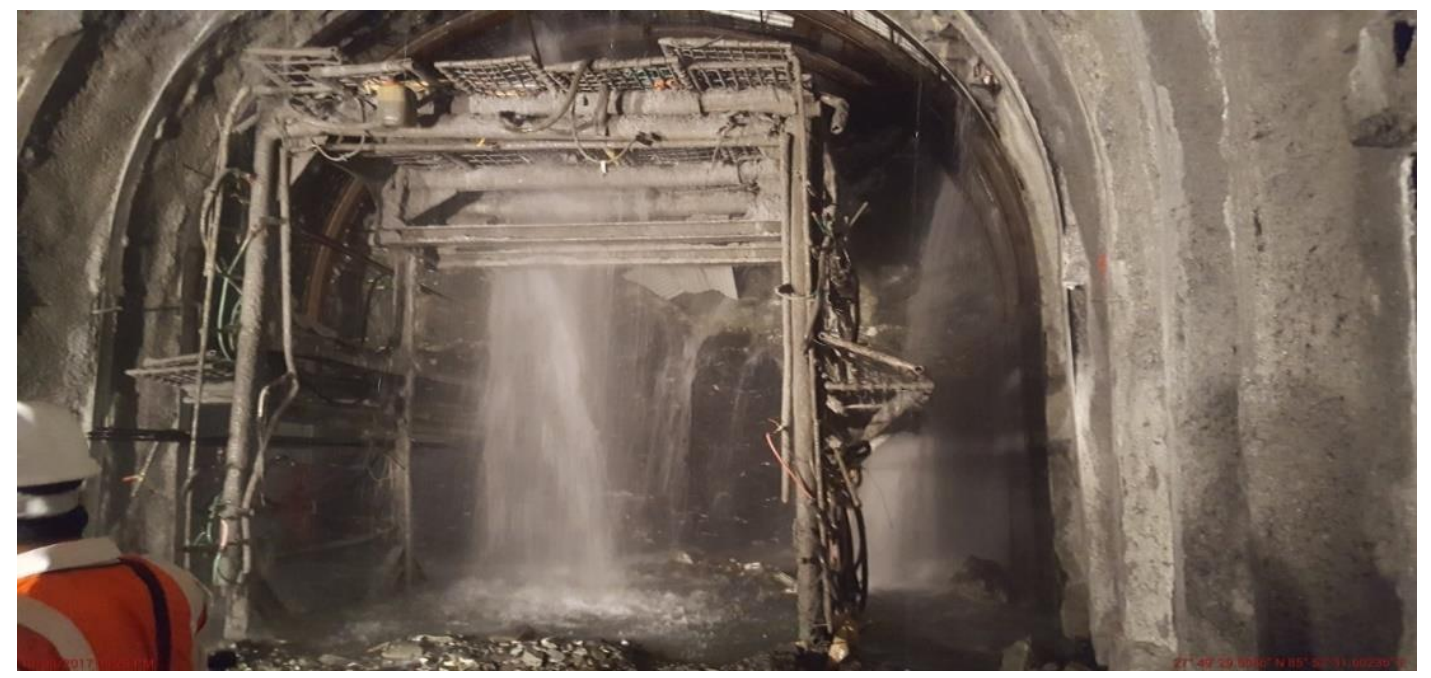

Plate 4.3: See page water coming from crown part of tunnel

Plate 4.3 shows seepage water coming from the crown part of the tunnel which disturbs the support works of tunnel causing the high risk of accident. 


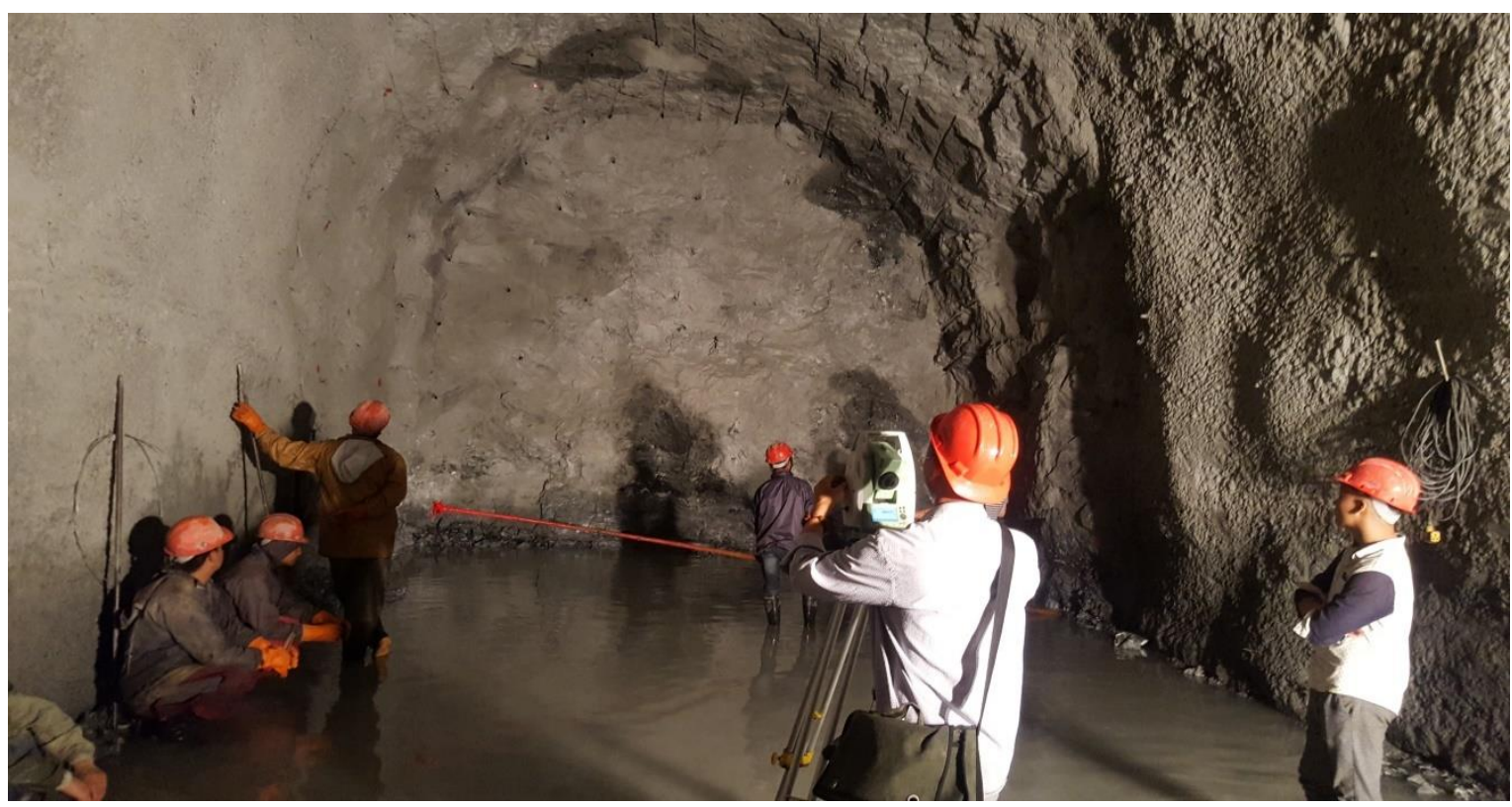

Plate 4.4: Water inundation inside HRT

Plate 4.4 shows the water inundation inside tunnel which is disturbing the surveying and other works in tunnel causing the risk of bad health environment. There was not pumping system of water used. If seepage water is not controlled immediately or soon, it will scour or make the geology in particular portion week and more unstable leading to rock fall and collapse of tunnel which cause accident and injury.

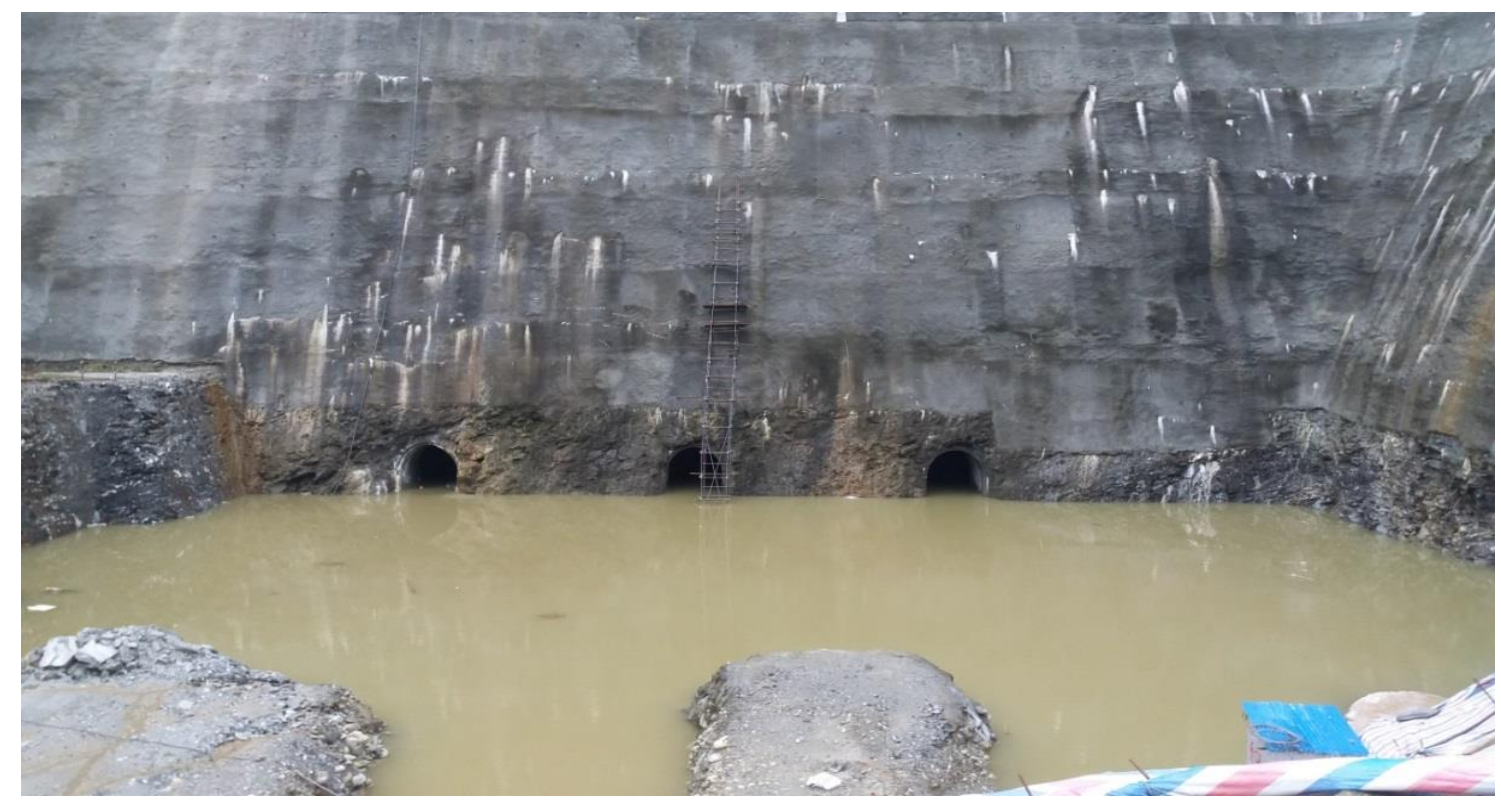

Plate 4.5: Water inundation at outlet of tri-furcation tunnel in PH Site

The plate 4.5 shows the water poundage created due to inundation of water in front of tri-furcation tunnel of power house. There was risk of drowning the workers due to the inundation of water during the tunnel construction. No pumping system was continued. 


\subsubsection{Medical Examinations}

Table 4.6 shows that the current provision of medical examination facility made at construction site. Exactly $100 \%$ workers responded that there was no medical examination facility provided at site but $80 \%$ of employer responded that there was medical examination once in a project.

Table 4.6: Provision of medical examination

\begin{tabular}{|l|l|l|l|l|l|}
\hline \multicolumn{2}{|l|}{} & \multicolumn{2}{l|}{ Employer } & \multicolumn{2}{l|}{ Workers } \\
\cline { 2 - 6 } & & Number|Percent Number & Percent \\
\hline \multirow{3}{*}{ Provision of medical examination } & Monthly & 0 & $0 \%$ & 0 & $0 \%$ \\
\cline { 2 - 6 } & In every six month & 0 & $0 \%$ & 0 & $0 \%$ \\
\cline { 2 - 6 } & Yearly & 2 & $80 \%$ & 0 & $0 \%$ \\
\cline { 2 - 6 } & Once in project & 8 & $20 \%$ & 0 & $0 \%$ \\
\hline & Never & 0 & $0 \%$ & 37 & $100 \%$ \\
\hline
\end{tabular}

Even though the all workers responded that there was no and never any medical examination, most of the employers responded that they had its provision in yearly basis. There was conflict between their responses. And key informant interview was done with some personnel of Client/Consultant and some of the locals which shows contractor had not provided any medical examination in yearly basis at Site. Key informant interview with contractor's manager shows that they had done agreement with Key Stone Hospital Pvt. Ltd. located at Bahrabise 4km downstream of Power House Site and used to provide the medical examination in serious case only for treatment.

\subsubsection{Risk Rating Matrix}

Table 4.7: Risk rating matrix

\begin{tabular}{|c|c|c|c|c|c|}
\hline \multicolumn{6}{|c|}{ Risk Score $=$ Consequences $(\mathrm{C}) \times$ Likelihood $(\mathrm{L})$} \\
\hline S.N & Occupational Hazards & $\begin{array}{c}\text { Consequences } \\
(1-5)\end{array}$ & $\begin{array}{l}\text { Likelihood } \\
\text { (1-5) }\end{array}$ & $\begin{array}{c}\text { Risk } \\
\text { Score }\end{array}$ & $\begin{array}{c}\text { Risk level } \\
\text { Rating }\end{array}$ \\
\hline 1 & Sound/Noise & 1.35 & 5 & 6.75 & Moderate \\
\hline 2 & Vibrations & 3 & 4.45 & 13.35 & High \\
\hline 3 & Lighting & 2 & 3.8 & 7.6 & Moderate \\
\hline 4 & Electric Hazards & 4 & 4 & 16 & High \\
\hline 5 & Rock Fall Hazards & 5 & 4.3 & 21.5 & Critical \\
\hline 6 & Heat \& Humidity & 1.9 & 4.85 & 9.215 & Moderate \\
\hline 7 & Radiations & 4 & 1 & 4 & Low \\
\hline 8 & Toxic Gases (Ammonia etc.) & 2 & 5 & 10 & Moderate \\
\hline 9 & $\begin{array}{l}\text { Dust Hazards (sand, cement, silica } \\
\text { etc.) }\end{array}$ & $\mathrm{a} 2$ & 5 & 10 & Moderate \\
\hline 10 & Chemical Spills & 2 & 4.05 & 8.1 & Moderate \\
\hline 11 & Unprotected Edges & 3 & 2 & 6 & Moderate \\
\hline 12 & Mechanical Struck & 4 & 1 & 4 & Low \\
\hline 13 & Slippery & 2 & 2 & 4 & Low \\
\hline 14 & Tripping & 3 & 3 & 9 & High \\
\hline 15 & Fall from platform & 3 & 1.6 & 4.8 & Low \\
\hline
\end{tabular}


16 Hit by aggregate

17 Water Inundation

18 Job dissatisfaction

19 Job Insecurity

20 Deadline Pressure

21 Hot and Humid Work Environment

22 Oxygen Deficiency

23 Bat Biting

24 Snake Bites

25 Alcoholism

26 Ergonomics

\begin{tabular}{|l|l|l|l|}
2 & 2.15 & 4.3 & Low \\
\hline 1 & 3 & 3 & Low \\
\hline 1 & 4.6 & 4.6 & Low \\
\hline 1 & 4.45 & 4.45 & Low \\
1 & 2.85 & 2.85 & Low \\
\hline 2 & 4.75 & 9.5 & Moderate \\
\hline 2 & 4.05 & 8.1 & Moderate \\
\hline 2 & 1 & 2 & Low \\
\hline 4 & 1 & 4 & Low \\
\hline 3 & 1.75 & 5.25 & Low \\
\hline 2 & 4.325 & 8.65 & Moderate \\
\hline
\end{tabular}

\subsubsection{Rating Matrix in Reverse Chronological Order}

Table 4.8: Risk rating matrix in reverse chronological order

\begin{tabular}{|c|c|c|c|c|c|}
\hline \multicolumn{6}{|c|}{ Risk Score $=$ Consequences $(\mathrm{C}) \mathrm{X}$ Likelihood $(\mathrm{L})$} \\
\hline S.N & Hazards & \begin{tabular}{|c} 
Consequences \\
$(1-5)$
\end{tabular} & $\begin{array}{c}\text { Likelihood } \\
(1-5)\end{array}$ & \begin{tabular}{|c|} 
Risk \\
Score
\end{tabular} & $\begin{array}{c}\text { Risk level } \\
\text { Rating } \\
\end{array}$ \\
\hline 1 & Rock Fall Hazards & 5 & 4.3 & 21.5 & Critical \\
\hline 2 & Electric Hazards & 4 & 4 & 16 & High \\
\hline 3 & Vibrations & 3 & 4.45 & 13.35 & High \\
\hline 4 & Toxic Gases (Ammonia etc.) & 2 & 5 & 10 & Moderate \\
\hline 5 & $\begin{array}{l}\text { Dust Hazards (sand, cement, silic } \\
\text { etc.) }\end{array}$ & 2 & 5 & 10 & Moderate \\
\hline 6 & Hot and Humid Work Environment & 2 & 4.75 & 9.5 & Moderate \\
\hline 7 & Heat \& Humidity & 1.9 & 4.85 & 9.215 & Moderate \\
\hline 8 & Tripping & 3 & 3 & 9 & Moderate \\
\hline 9 & Ergonomics & 2 & 4.325 & 8.65 & Moderate \\
\hline 10 & Chemical Spills & 2 & 4.05 & 8.1 & Moderate \\
\hline 11 & Oxygen Deficiency & 2 & 4.05 & 8.1 & Moderate \\
\hline 12 & Lighting & 2 & 3.8 & 7.6 & Moderate \\
\hline 13 & Sound/Noise & 1.35 & 5 & 6.75 & Moderate \\
\hline 14 & Unprotected Edges & 3 & 2 & 6 & Moderate \\
\hline 15 & Alcoholism & 3 & 1.75 & 5.25 & Low \\
\hline 16 & Fall from platform & 3 & 1.6 & 4.8 & Low \\
\hline 17 & Job dissatisfaction & 1 & 4.6 & 4.6 & Low \\
\hline 18 & Job Insecurity & 1 & 4.45 & 4.45 & Low \\
\hline 19 & Hit by aggregate & 2 & 2.15 & 4.3 & Low \\
\hline 20 & Radiations & 4 & 1 & 4 & Low \\
\hline 21 & Mechanical Struck & 4 & 1 & 4 & Low \\
\hline 22 & Slippery & 2 & 2 & 4 & Low \\
\hline 23 & Snake Bites & 4 & 1 & 4 & Low \\
\hline 24 & Water Inundation & 1 & 3 & 3 & Low \\
\hline 25 & Deadline Pressure & 1 & 2.85 & 2.85 & Low \\
\hline 26 & Bat Biting & 2 & 1 & 2 & Low \\
\hline
\end{tabular}


Table 4.8 shows the risk rating matrix in reverse chronological order. Risk score has been calculated by multiplying the consequences by likelihood. Priority of preventive and control measures should be given according to the hierarchy of risk level i.e. as per the rating of risk level.

Rock fall hazard seems to have the critical level of risk. So, immediate action is needed. To control rock fall hazard, weak part of rock mass must be protected by applying rock bolts, wire mesh shotcrete etc. carefully. Proper geological scaling should be done by expert before starting primary support works. Hard hats must be worn. Warning sign should be provided near rock fall hazards.

Electrical hazards and vibrations have been revealed as hazards with high risk level. So, preventive and control measures must be applied within 1-2 days. The task should not proceed unless the risk is assessed and control options selected based on the hierarchy of controls. In case of electrical hazards, proper fencing and barricade must be applied to make the high voltage area safe. Bare electric wire must be insulated with good insulator. Dry and insulating dress must be worn during working with electricity. Electrical wire should not be laid freely on the working ground. In case of vibration hazards, equipment must be carefully handled. Proper hand gloves must be worn during the operation of equipment like jack hammer. After working with vibrations, proper massage of body parts like hands, wrist, and arm must be done with suitable massage oil. As far as possible vibrations absorber must be used during working with vibrations.

Toxic gases, dust hazards, hot and humid work environment, heat and humidity, tripping, ergonomics, chemical spills, oxygen deficiency, lighting, noise/sound and unprotected edges have the moderate risk level as shown in above table. So, action is required within a week to eliminate or minimize the risk using the Hierarchy of Controls. Immediately after blasting, toxic gases like ammonia is released from blasting face. So, before check in proper defuming must be done with proper provision of ventilation system. During mucking and other activities equipment like loader, excavator etc. release harmful gases like carbon dioxide and carbon monoxide. So working place inside tunnel must be properly ventilated. Proper air dust filter breathing mask must be worn inside tunnel during work. From blasting face and operation of other equipment release heat and thus proper cooling system should be arranged. Joint of air and water circulation pipe must be properly connected and secured so as to minimize the injury. Proper connection of electrical supply system of electricity must be maintained. Switch, board etc. should be continuously checked every day before use. Material safety data sheet (MSDS) must be thoroughly read before use of chemicals. Proper chemical proof hand gloves should be used before handling chemicals. To make continuous supply of oxygen during work sufficient ventilation duct and blower fans must be installed and compressor must always be in good condition. Proper electric bulb must be used to make good visibility. Air plug must be used to avoid the noise and sound. Unprotected edges must not be left carelessly and must be fenced properly.

Other hazards having low level of risk in workplace are alcoholism, fall from platform, job dissatisfaction, job Insecurity, hit by aggregate, radiations, mechanical struck, slippery, snake bites, water inundation, deadline pressure and bat biting etc. These hazards should not be ignored thinking as low risk because sometime small thing can bring larger and worse condition. Action is required within a reasonable timeframe (2-4 weeks) to eliminate or minimize the risk using the hierarchy of controls. 


\section{Conclusions}

Identifying occupational hazards and assessing their risk provide necessary feedback for applying prevention and control measures at work site. Noise, vibrations were the major physical hazards, chemical spills and cement/silica/sand dust as major chemical hazard, fall from working platform, slippery, rock sliding, hit by aggregate, as major mechanical hazard and job dissatisfaction, job insecurity were noted as major psychosocial hazard at tunnel. The major risks due to occupational hazards were identified as back pain, wrist pain, hearing loss, eye strain, skin allergy, irrigative, corrosive.

Risk level of rock fall hazard has been revealed as the highest as risk score of 21.5 and fall under "Critical" risk level rating. Electric hazard and vibration have been found to have the risk score of 16 and 13.35 respectively both having risk rating level of "High". Toxic gases like ammonia gases, dust hazards, hot and humid work environment, heat and humidity, tripping, ergonomics, chemical spills, oxygen deficiency, lighting, noise/sound and unprotected edges have been found to have risk scores 10,10,99.5,9.215,9,8.65,8.1,8.1,7.6,6.75,6 respectively which all fall under the risk level rating of "Moderate". Other hazards having "Low" risk rating level were alcoholism, fall from platform, job dissatisfaction, job Insecurity, hit by aggregate, radiations, mechanical struck, slippery, snake bites, water inundation, deadline pressure and bat biting with respective risk scores $5.25,4.8,4.6,4.45,4.3,4,4,4,4,3,2.85,2$.In construction of head race tunnel, the most dangerous and risky activity was found as drilling and blasting and geological scaling and mapping and support works were also the equally risky activity in the tunnel. It was found that contractor should be more responsible for the accident at site.

\section{References}

[1] Alli, B.O., 2008. Fundamental principles of occupational health and safety. Second Edi. Geneva: International Labour office.

[2] Heavan, A., 2012. Construction Safety, a case study in Nepal. [Online] Available at:

[3] http://angelheaven411.blogspot.com/ [Accessed 24th April 2016].

[4] ILO, International Labour standards on occupational safety and health, 1919. International

[5] Labour standards on occupational safety and health. ILO.

[6] ILO, 1996. Introduction to occupational health and safety. International Labour Organization

[7] ILO, 2003. Decent construction work in Nepal. International Labour Organisation.

[8] Katmandu, Nepal

[9] HSE, 2014. Risk Assessment. UK, Health \& Safety Executive (HSE),

[10] WSU, 2015. Hazard Identification, Risk Assessment and Control Procedure, Australia, Western Sydney University (WSU)

\footnotetext{
*Corresponding author.

E-mail address: anjaymishra2000@ gmail.com
} 